\title{
Pediatrik COVID-19 Vakalarında Akciğer Bilgisayarlı Tomografisi Ne Kadar Değerli ?
}

\section{How Valuable is Chest Computed Tomography in Pediatric Patients with COVID-19?}

\author{
${ }^{1}$ Aysun BOGA, ${ }^{2}$ Nurettin YIYIT, ${ }^{3}$ Umut ERGUL, ${ }^{1}$ Nese ERGUL, ${ }^{1}$ Kemal PISMISOGLU, \\ ${ }^{3}$ Yusuf Taha KUZAN, ${ }^{4}$ Murat CIHAN, ${ }^{1}$ Şirin GUVEN, ${ }^{1}$ Halit CAM

\footnotetext{
${ }^{1}$ University of Health Science, Department of Pediatrics, Prof. İlhan Varank Sancaktepe Training \& Research Hospital, Istanbul, Turkey

${ }^{2}$ University of Health Science, Department of Thoracic Surgery, Prof. İlhan Varank Sancaktepe Training \& Research Hospital, Istanbul, Turkey

${ }^{3}$ University of Health Science, Department of Radiology, Prof. İlhan Varank Sancaktepe Training \& Research Hospital, Istanbul, Turkey
} \\ ${ }^{4}$ University of Ordu, Department of Biochemistry, Ordu Faculty of Medicine Training \& Research Hospital, Ordu, Turkey
}

\author{
Aysun Boga: https://orcid.org/0000-0002-9574-9529 \\ Nurettin Yiyit: https://orcid.org/0000-0003-1671-7498 \\ Umut Ergul: https://orcid.org/0000-0003-2090-9222 \\ Neşe Ergul: https://orcid.org/0000-0002-2665-5326 \\ Kemal Pismisoglu: https://orcid.org/0000-0001-7278-309X \\ Yusuf Taha Kuzan: https://orcid.org/0000-0002-5420-8507 \\ Murat Cihan: https://orcid.org/0000-0001-6611-7226 \\ Şirin Guven: https://orcid.org/0000-0001-8727-5805
}

\section{ÖZ}

Amaç: COVID-19'lu pediatrik hastaların tanı ve tedavisinde bilgisayarlı göğüs tomografisinin (BT) önemini araştırmayı amaçladık.

Materyal ve Metot: Mart 2020-Nisan 2020 tarihleri arasında çocuk kliniğimizde COVID-19 şüphesi ile izlenen 45 çocuk hastanın klinik ve radyolojik bulguları, hastanemizin elektronik kayit sisteminden elde edilerek değerlendirildi.

Bulgular: Olguların 24'ü k1z, 21'i erkek ve ortanca yas 177 (20-215) aydı. Otuz iki hastanın SARS-CoV-2 RTPCR sonucu pozitif, 13 hastanın ise negatifti. En s1k görülen semptom öksürük (\%87) idi. Hastaların \%73.3'ünde COVID-19 tanısı olan kiși ile temas öyküsü vardı. Olguların 30'unda COVID-19 u düşündüren göğüs BT bulguları vardı. RT-PCR sonuçları ile akciğer BT bulguları arasında anlamlı ilişki yoktu. Akciğer BT derecelendirmesi ile serum CRP düzeyleri arasında anlamlı ilişki bulundu ( $\mathrm{p}<$ $0.01)$.

Sonuç: Çalışmamızda pediatrik olgularda göğüs BT'nin COVID-19 tanısında ek bir avantajı olmadığın gözlemledik. Bu nedenle, CT ilişkili potansiyel radyasyona maruziyet dikkate alındığında, doktorlar çocuklarda klinik bulgulara dikkat etmeli.

Anahtar Kelimeler: Akciğer BT, COVID-19, çocuk

\section{ABSTRACT}

Objective: We aimed to investigate the importance of chest computerized tomograpgy (CT) in diagnosis and treatment of pediatric patients with COVID-19.

Materials and Methods: The clinical and radiological findings of 45 children with suspected COVID-19 admited to our pediatric clinic between March and April, 2020 were retrospectively valuated from medical records.

Results: The median age was 177 (range 20-215) months, 24 of the patients were girl sand 21 were boys. RT-PCR results of 32 children were SARS-CoV-2 positive and 13 out of 45 tests were negative. The most common symptom was cough $(87 \%) .73 .3 \%$ of the patients had a history of contact with an infected person. Chest CT findings revealed as COVID-19 among 30 children. There was no significant relationship between RT-PCR results and chest $\mathrm{CT}$ findings. A significant correlation was found between chest CT severity and serum CRP levels ( $p$ $<0.01)$.

Conclusion: In our study, we observed that chest CT does not have an additional advantage in COVID-19 diagnosis in pediatric cases. Therefore, considering the potential radiation exposure associated with $\mathrm{CT}$ scan, physicians should beware of Clinical symptoms in children.

Keywords: Chest CT, children, COVID-19
Sorumlu Yazar / Corresponding Author:

Aysun Boga

Sarigazi Emek, Namik Kemal Cd. No:7 34785, Sancaktepe/Istanbul

Tel: +905333447808

E-mail: aysunboga@gmail.com
Yayın Bilgisi / Article Info:

Gönderi Tarihi/ Received: 10/07/2020

Kabul Tarihi/ Accepted: 01/10/2020

Online Yayın Tarihi/ Published: 30/12/2020

Atıf / Cited: Boğa A et al. How Valuable is Chest Computed Tomography in Pediatric Patients with COVID-19? Online Türk Sağlık Bilimleri Dergisi 2020;5(4):572-581. doi: 10.26453/otjhs.767400 


\section{INTRODUCTION}

The new coronavirus 2019 (2019-nCoV), which first appeared in Wuhan, China's Hubei province in December 2019, was reported by the World Health Organization as a cause of coronavirus disease 2019 (COVID-19) on February 11, 2020. ${ }^{1,2}$ The 2019$\mathrm{nCoV}$, also referred to as Severe Acute Respiratory Syndrome Coronavirus 2 (SARS-CoV-2) by The International Committee on Taxonomy of Viruses, has increasingly spread all over the world and was declared a global epidemic on March 11, 2020. ${ }^{3,4}$ The incidence of COVID-19 in children is relatively low frequent and milder comparing with adults. The clinical and imaging findings of pediatric patients with COVID-19 infection were limited. ${ }^{5}$ In published studies, the prevalence of pediatric COVID-19 is between $0.8 \%$ and $4.8 \%$, and $90 \%$ of the cases are asymptomatic or present with mild symptoms. ${ }^{6-8}$

A growing number of published studies, systematic review and meta-analysis determined the clinical characteristics and diagnostic features of COVID19. ${ }^{7-9}$ In the laboratory findings, characteristic have not been determined yet in children with COVID-19. Studies have reported an increase in lymphopenia and elevation of inflammatory markers, such as Creactive protein (CRP) and erythrocyte sedimentation rate (ESR) ${ }^{6,8}$ While conducting (performing) this study, we aimed to evaluate the importance of chest computed tomography (CT) in diagnosis and treatment of pediatric COVID-19 cases. ${ }^{8}$

\section{MATERIALS AND METHODS}

This study started after the approval of the University of Health Sciences, Umraniye Training and Research Hospital Medical Scientific and Ethical committee (Date: 28/04/2020, decision no: 139). 235 suspected or confirmed COVID-19 cases aged between 0 and 18 years, who admitted to the Pediatric Emergency Unit of Sancaktepe Training and Research Hospital between March 11, 2020 and April 26,2020 , was retrospectively evaluated. Seventythree cases required chest $\mathrm{CT}$ due to underlying disease, abnormal vital signs or physical examination findings, and worsening during follow-up were evaluated. Twenty-eight cases were excluded due to negative real-time reverse-transcriptase-polymerasechain-reaction (RT-PCR) test for SARS-CoV-2, normal chest $\mathrm{CT}$ images, incompatible $\mathrm{CT}$ findings with COVID-19.

Patients' age, gender, contact history, symptoms, disease severity, RT-PCR results, white blood cell
(WBC) count and serum C-reactive protein (CRP) levels, radiological imaging features, and details about the follow-up period and treatment, were recorded. Chest CT findings were evaluated by two experienced radiologists in accordance with the Thoracic Imaging for COVID-19 Infection version 2 of the British Society of Thoracic Imaging (BSTI). ${ }^{10}$

CT results were categorized as normal, probable COVID-19 and classic COVID-19, indeterminate COVID-19 and non-COVID-19 according to the BSTI $^{10}$. The COVID-19 disease severity was evaluated with clinical and imaging findings: ${ }^{11}$

- Asymptomatic; cases without clinical symptoms, normal chest radiography and positive RT-PCR or serum specific antibody test.

- Mild; cases with symptoms of upper respiratory tract infections or gastrointestinal symptoms (such as nausea, vomiting, abdominal pain and diarrhea) without pneumonia.

- Moderate; cases with typical COVID-19 signs and symptoms (such as fever, cough, shortness of breath, and signs of listening in the lungs) and / or chest imaging that suggest pneumonia.

- Severe; cases with tachypnea, oxygen saturation $\leq 92$ on room air, dyspnea, confusion, nutritional difficulties and dehydration.

- Critical; cases with multiorgan insufficiency, shock, mechanical ventilation requirement or followed at intensive care unit.

Statistical analysis of data was performed using SPPS 22.0; Analyz-it and Medcalc statistical programs. Demographic data are summarized as number, mean and standard deviation. To test if the data set fits the normal distribution curve, the Kolmogorov-Smirnov test was used for samples larger than 50 , and the Shapiro-Wilk test was used for smaller samples. The comparison of categorical variables was performed using Fisher's exact test. For the comparison of two groups of numerical values, the Mann-Whitney U test was used for samples without normal distribution, and the independent samples ttest was used for samples with normal distribution. Mann Whitney U test was used to compare numerical values in three groups for samples without normal distribution, and one-way analysis of variance (ANOVA) was used for samples with normal distribution. After multiple comparisons to assess which 
group(s) caused the differences, Bonferroni comparison test used. Spearman's rho correlation test was used to compare samples with continuous variables. In all tests we accepted statistical significance level as $\mathrm{p}<0.05$.

\section{RESULTS}

The clinical and radiological findings of 45 children with suspected COVID-19 have been evaluated. The median age was 177 (range 20 - 215) months, 24 (53\%) were girls and $21(47 \%)$ were boys. Among symptomatic cases, $12(27 \%)$ had no previous exposure history, 21 (46\%) had one, $12(27 \%)$ had two contact history. The most common symptom was cough $(39 / 45,87 \%)$, the least common symptom was loss of smell and taste $(2 / 45,4 \%)$. Eighteen cases had multiple symptoms $(18 / 45,40 \%)$. Fever $10(22 \%)$, respiratory distress $8(18 \%)$ and vomiting / diarrhea were observed in 8 (18\%) cases. Fourteen $(31 \%)$ cases were classified as mild, $26(58 \%)$ cases as moderate, $2(4 \%)$ cases as severe, $3(7 \%)$ cases as critical according to the disease severity. Twenty-three $(51 \%)$ patients were hospitalized, and $22(49 \%)$ patients were followed at home (Table 1). RT-PCR result was positive for SARS-CoV-2 in 32 (71\%) patients and negative in $13(29 \%)$ patients.

Laboratory and radiological findings of cases were shown in Table 2. Lymphopenia was found in 20 (44.4\%), and elevated serum CRP levels in 25 (55.5\%) patients. Chest radiography was performed in 40 children, it was observed that $18(45 \%)$ of them 40 children had normal chest radiography and 22 (55\%) had abnormal findings. A significant inverse correlation was found between haemoglobin levels and serum CRP levels, and neutrophil lymphocyte ratio (NLR) (p: 0.03, p <0.01, respectively). Furthermore, a significant correlation was found among platelet and eosinophil, lymphocyte, neutrophil and WBC values $(p=0.02, p<0.01, p<0.01, p$ $<0.01)$.

When we evaluated chest $\mathrm{CT}$ images according to the RT-PCR results, 14 (31\%) images were normal, $26(58 \%)$ were consistent with classic / probable COVID-19, four (9\%) were indeterminate for COVID-19 and one (2\%) was non COVID-19 (Figure 1). The CT scan images were severe only in $5(16.7 \%)$ out of 30 children with classic/probable/ indeterminate COVID-19 predominant pattern, moderate in $8(26.7 \%)$ and mild in 17 (56.6\%). A significant correlation was found between chest $\mathrm{CT}$ severity and C-reactive protein $(\mathrm{CRP})(\mathrm{p}<0.01)$ ( Figure 2). Figure 3 shows the chest radiography and CT scan image of a 10-year-old girl (SARS-CoV-2 positive) with a contact history, fever, cough and fatigue.

\section{DISCUSSION AND CONCLUSION}

It has been reported that the new coronavirus rarely affects children however might be present with different symptoms. ${ }^{5-8} \mathrm{We}$ conducted this study to investigate whether there are different findings to help us diagnose COVID-19 in children. Studies revealed that children of all ages are susceptible to SARSCoV-2 infection. In United States, among 2.572 children with COVID-19, the median age was 11 years (range 0-17 years) and the majority of children were aged 15-17 years, ${ }^{11}$ like our study. Contrary to slightly male predominance in published studies, the gender difference (53\% female, $47 \%$ male) in our study was found not significant. ${ }^{12,13} \mathrm{Ma}$ et al. ${ }^{12}$ evaluated 50 children with SARS-CoV-2 with rt-PCR and they reported that the most common symptom was fever (64\%). They showed that six of the cases $(12 \%)$ were asymptomatic. In our study, the most common symptom was cough $(87 \%)$, the least common symptom was loss of taste and smell, and the severity of the disease was mild / moderate in $96.9 \%$ of cases like previously published pediatric reports. ${ }^{12-14}$ Many studies have reported that the transmission of disease in children is by close contact with infected persons, more than $65 \%$ of patients had an history with household contact. ${ }^{13,15,16}$ Likewise, in our study, 28 of the RT-PCR positive cases $(28 / 32,87.5 \%)$ and 33 of all cases $(33 / 45, \%$ 73) had contact history. Specific laboratory findings of pediatric COVID-19 cases have not been reported in the literature. Most frequently, lymphopenia (16\% to $35 \%$ ), lymphocytosis ( $8 \%$ to $15 \%$ ), elevated CRP levels $\left(20 \%\right.$ to $45 \%$ ) were reported. ${ }^{12,13,16}$ Nearly half of our cases had lymphopenia (44.4\%) and elevated CRP (55.5\%) levels. This difference can be explained by the reference values that we used according to the age and gender. This difference can be explained by the reference values that we used according to the age and gender. The inverse correlation between serum CRP and hemoglobin levels was thought to be associated with susceptibility to infections in anemicchildren. ${ }^{17}$ Our finding suggests that CRP may be one of the markers showing the severity of lung injury in the early stage of COVID-19.

Until now, RT-PCR is the most commonly used test in the diagnosis of COVID-19. However, the negative result of RT-PCR cannot precisely exclude the disease. ${ }^{18,19}$ Therefore, some studies have focused on comparing RT-PCR with other diagnostic methods. 
Fang et al. $^{20}$ assessed 51 adult patients, and they reported that the chest CT sensitivity (98\%) was higher than the RT-PCR (71\%) for the diagnosis of COVID-19.Systematic review including 92 studies, showed that the sensitivity of chest $\mathrm{CT}$ scan ranged between $50 \%$ and $74 \% .{ }^{18}$ In accordance with these findings, our study, although it was not statistically significant, the chest CT sensitivity (67\%) was lower than the RT-PCR sensitivity (71\%). Chen et al. ${ }^{21}$ suggested chest $\mathrm{CT}$ as one of the optional criteria in pediatric patients.

Nonetheless, some authors suggested that we need chest CT scan examinations to guide diagnosis and treatment in clinically suspected RT-PCR negative cases. ${ }^{13,22-24}$ Given the radiation exposure, chest CT should not be considered routinely in children and pregnant women; clinicians should rely on clinical symptoms. ${ }^{12,25}$ Feng et al. ${ }^{26}$ concluded that positive chest CT does not affect the diagnosis, and treatment of the cases and that repeated chest CT does not have a significant benefit in follow-up of these patients. All these studies in consistence with our results, showed that unlike adults, chest CT scan does not have an advantage for diagnosis of COVID-19 in children.

COVID-19 might be associated with other respiratory pathogens such as influenza $\mathrm{A}$ and $\mathrm{B}$, mycoplasma, respiratory syncytial virus and cytomegalovirus, in these cases images can overlap and it is difficult to differentiate whether lung findings are related to COVID-19. ${ }^{13,27}$ In our study, a few cases with influenza virus were excluded from the study.

Our result shows that nearly $50 \%$ of children had normal CT findings. Similar to the previously published results we found that in $44 \%$ of PCR positive children, the chest CT scan images were normal. ${ }^{15,18}$ In addition, studies have reported that most of the cases with positive RT-PCR and chest CT consistence with COVID-19 are generally mild to moderate, as found in our study $(88,2 \%) .{ }^{8,13,24,28,29}$ However, different advices are suggested on this subject. There are publications suggesting chest CT in the early stage of the disease or for patient followup. $^{13,24,26}$ The guideline for medical imaging recommends that the chest CT might be considered at a low dose in the diagnosis and follow-up imaging might be recommended only in children of clinical deterioration. ${ }^{23}$ The limitation of our study was the relatively low number of cases with performed $\mathrm{CT}$ scans.

In conclusion, COVID-19 in children usually is asymptomatic or presents with mild upper respirato- ry symptoms. The CT scan injury is mild to moderate even in symptomatic children. Therefore, the possible harmful effects of radiation should be considered and chest CT scan should be performed in selected pediatric patients.

Ethics Committee Approval: This study started after the approval of the University of Health Sciences, Umraniye Training and Research Hospital Medical Scientific and Ethical Committee (Date: 28/04/2020, decision no: 139)

Conflict of Interest: No conflict of interest was declared by the authors.

Author Contributions: Concept- AB, SG, NY; Supervision- AB, SG; Materials-AB, UE, NE, YTH; Data Collection and Processing $\mathrm{KP}, \mathrm{MC}, \mathrm{AB}$; Analysis and Interpretation- $\mathrm{AB}, \mathrm{SG}$; Writing- $\mathrm{AB}$, $\mathrm{SG}, \mathrm{HC}$.

Peer-review: Externally peer-reviewed.

\section{REFERENCES}

1. World Health Organization. Novel coronavirus China2020. https://www.who.int/csr/don/12january-2020-novel-coronaviruschina/en/. Accessed 15 Feb 2020.

2. International committee on taxonomy viruses naming the 2019coronavirus2020. https:// talk.ictvonline.org/. Accessed 15 Feb 2020.

3. World Health Organization. Novel coronavirus (2019-nCoV) situation report - 222020. https:// www.who.int/docs/default-source/ coronaviruse/situation-reports. /20200211-sitrep-22ncov.pdf?sfvrsn= fb6d49b1_2. Accessed 15 Feb 2020.

4. World Health Organization. Novel coronavirus (2019-nCoV) situation report - 1172020. https://www.who.int/docs/default-source/ coronaviruse/situation-reports. Accessed 16 May 2020.

5. Yasuhara J, Kuno T, Takagi H, Sumitomo N. Clinical characteristics of COVID-19 in children: A systematic review. Pediatr Pulmonol. 2020;55:2565-2575.

6. Tagarro A, Epalza C, Santos M, et al. Screening and severity of Coronavirus Disease 2019 (COVID-19) in Children in Madrid, Spain. JAMA Pediatr. 2020. doi:10.1001/ jamapediatrics.2020.1346

7. Korean Society of Infectious D, Korean Society of Pediatric Infectious D, Korean Society of E, et al. Report on the Epidemiological Features of Coronavirus Disease 2019 (COVID-19) Out- 
break in the Republic of Korea from January 19 to March 2, 2020. J Korean Med Sci. 2020;35: e112.

8. Dong $\mathrm{Y}, \mathrm{Mo} \mathrm{X}, \mathrm{Hu} \mathrm{Y}$, et al. Epidemiology of COVID-19 among children in China. Pediatrics. 2020. doi:10.1542/peds.2020-0702

9. Guan WJ, Ni ZY, Hu Y, et al. Clinical characteristics of Coronavirus Disease 2019 in China. N Engl J Med. 2020;382:1708-1720.

10. British Society of Thoracic Imaging. Thoracic Imaging in COVID 19 Infection Guidance for the Reporting Radiologist Version 2.2020 https://www.bsti.org.uk/standards-clinicalguidelines/clinical-guidelines/bsti-covid-19guidance-for-the-reporting-radiologist/. Accessed 20 May 2020.

11. Centers for Disease Control and Prevention (CDC).Coronavirus Disease 2019 in Children COVID-19 Response Team. MMWR Morb Mortal Wkly Rep. 2020;69(14):422 .

12. Ma H, Hu J, Tian J, et al. A single-center, retrospective study of COVID-19 features in children: a descriptive investigation. BMC Med. 2020;18(1):123. doi:10.1186/s12916-020-01596 $-9$

13. Xia W, Shao J, Guo Y, Peng X, Li Z, Hu D. Clinical and $\mathrm{CT}$ features in pediatric patients with COVID-19 infection: Different points from adults. Pediatr Pulmonol. 2020;55(5):11691174. doi:10.1002/ppul.24718

14. Li Y, Cao J, Zhang X, et al. Chest CT imaging characteristics of COVID-19 pneumonia in preschool children: A retrospective study. BMC Pediatr. 2020;20(1):227. doi:10.1186/s12887020-02140-7

15. Lu Y, Wen H, Rong D, Zhou Z, Liu H. Clinical characteristics and radiological features of children infected with the 2019 novel coronavirus. Clin Radiol. 2020;75(7):520-525. doi:10.1016/ j.crad.2020.04.010

16. Zheng F, Liao C, Fan QH et al. Clinical characteristics of children with coronavirus disease 2019 in Hubei, China. Curr Med Sci. 2020;24:16. doi:10.1007/s11596-020-2172-6

17. Jonker FA, Boele van Hensbroek M. Anaemia, iron deficiency and susceptibility to infections. J Infect. 2014;69 Supp 11:S23-7.

18. Merkus PJ, Klein WM. Value of Chest CT as COVID 19 screening tool in children. Eur Respir J. 2020;2001241. doi:10.1183/13993003.01241-2020
19. Xie X, Zhong Z, Zhao W, Zheng C, Wang F, Liu J. Chest CT for typical 2019-nCoV pneumonia: relationship to negative RT-PCR testing. Radiology. 2020;296:41-45. doi:10.1148/ radiol.2020200343

20. Fang Y, Zhang H, Xie J, et al. Sensitivity of Chest CT for COVID-19: Comparison to RTPCR. Radiology. 2020;296:115-197. doi:10.1148/radiol.2020200432

21. Chen Z, Fu J, Shu Q, et al. Diagnosis and treatment recommendation for pediatric coronavirus disease-19. Zhejiang Da Xue Xue Bao Yi Xue Ban. 2020;49(1):1-8

22. DuanY, Zhu Y, Tang L, et al. CT features of novel coronavirus pneumonia (COVID-19) in children. EurRadiol. 2020;14:1-7. doi:10.1007/ s00330-020-06860-3

23. Li HJ, Liu SY, Xu HB, Cheng JL. Guideline for medical imaging in auxiliary diagnosis of coronavirus disease 2019. Chin J Med Imaging Technol. 2020;36:1-11.

24. Zhou Y, Yang GD, Feng K, et al. Clinical features and chest CT findings of coronavirus disease 2019 in infants and young children. Zhongguo Dang Dai Er Ke Za Zhi. 2020;22 (3):215-220. doi:10.1016/j.inf.2020.03.007

25. Liua H, Liub F, Li J, Zhanga T, Wanga D, Lanb W. Clinical and CT Imaging Features of the COVID-19 Pneumonia: Focus on Pregnant Women and Children. The Journal of Infection. 2020;80(5):7-13. doi:10.1016/j.jinf.2020.03.007

26. Feng K, Yun YX, Wang XF, et al. Analysis of CT features of 15 children with 2019 novel coronavirus infection. Zhonghua Er Ke Za Zhi. 2020;58(0):E007. doi:10.3760/cma.j.issn.05781310.2020.0007

27. Koo HJ, Lim S, Choe J, Choi SH, Sung H, Do KH. Radiographic and CT Features of Viral Pneumonia. Radiographics. 2018;38(3):719-39.

28. Wang D, Ju XL, Xie F, et al. Clinical analysis of 31 cases of 2019 novel coronavirus infection in children from six provinces (autonomous region) of northern China. Chin J Pediatr. 2020;58(4):269-274. doi: $10.3760 /$ cma.j.cn112140-20200225-00138

29. Li W, Cui H, Li K, Fang Y, Li S. Chest computed tomography in children with COVID-19 respiratory infection. Pediatr Radiol. 2020;50 (6):796-799. doi:10.1007/s00247-020-04656-7 
Table 1.The demographic characteristics of children with COVID-19.

\begin{tabular}{|l|c|}
\hline Age (n=45) & \\
\hline Median (Min-Max)-month & $177(20-215)$ \\
\hline Gender (n=45) n (\%) & $24(53)$ \\
\hline Female & $21(47)$ \\
\hline Male & $12(27)$ \\
\hline No of family members infected (n=45) n (\%) & $21(46)$ \\
\hline 0 contact & $12(27)$ \\
\hline 1 contact & \\
\hline$\geq 2$ contact & $39(87)$ \\
\hline Clinical Symptoms (n=45) $\mathbf{n}(\%)$ & $10(22)$ \\
\hline Cough & $2(4)$ \\
\hline Fever & $8(18)$ \\
\hline Smell/Taste loss & $8(18)$ \\
\hline Shortness of breath & \\
\hline Vomiting, diarrhea & - \\
\hline Clinical Severity $\mathbf{( n = 4 5 )} \mathbf{n}(\mathbf{\%})$ & $14(31)$ \\
\hline Asymptomatic & $26(58)$ \\
\hline Mild & $2(4)$ \\
\hline Moderate & $3(7)$ \\
\hline Severe & $22(49)$ \\
\hline Critical & $23(51)$ \\
\hline Follow-up (n=45) $\mathbf{n}(\mathbf{\%})$ & \\
\hline Home & \\
\hline Hospitalized & \\
\hline
\end{tabular}


Table 2.Evaluation of Laboratory and Radiological findings of Childrenwith COVID-19.

\begin{tabular}{|c|c|}
\hline \multicolumn{2}{|c|}{ RT-PCR (n=45) n (\%) } \\
\hline Positive & $32(71)$ \\
\hline Negative & $13(29)$ \\
\hline \multicolumn{2}{|l|}{ White-cell count $(n=45)$} \\
\hline Mean(Min-Max)-cells $/ \mathrm{mm}^{3}$ & $7100(2500-26200)$ \\
\hline \multicolumn{2}{|c|}{$\operatorname{ANC}^{*}(\mathrm{n}=45)$} \\
\hline Mean(Min-Max)-cells $/ \mathrm{mm}^{3}$ & $4750(1090-22910)$ \\
\hline \multicolumn{2}{|c|}{$\operatorname{ALC}^{* * *}(n=45)$} \\
\hline Mean(Min-Max)-cells $/ \mathrm{mm}^{3}$ & $1740(640-3870)$ \\
\hline \multicolumn{2}{|c|}{$\operatorname{NLR}^{k * * *}(n=45)$} \\
\hline Mean(Min-Max) & $2.33(0.53-31.9)$ \\
\hline \multicolumn{2}{|c|}{ Eosinophil $(n=45)$} \\
\hline Mean(Min-Max)-cells $/ \mathrm{mm}^{3}$ & $80(0-650)$ \\
\hline \multicolumn{2}{|c|}{ Platelet count $(n=45)$} \\
\hline $\begin{array}{l}\text { Mean-cells } / \mathrm{mm}^{3} \\
\text { (Min-Max)-cells } / \mathrm{mm}^{3}\end{array}$ & $\begin{array}{c}241000 \\
(159000-407000) \\
\end{array}$ \\
\hline \multicolumn{2}{|c|}{ Hemoglobin (n=45) } \\
\hline Mean(Min-Max)-gr/dl & 13.4(9.4-17) \\
\hline \multicolumn{2}{|c|}{ C-reactive protein $(n=45)$} \\
\hline Mean(Min-Max)-mg/dl & $0.07(0-40)$ \\
\hline \multicolumn{2}{|c|}{ Chest X-Ray (n=40) n (\%) } \\
\hline Normal & $18(45)$ \\
\hline Abnormal & $22(55)$ \\
\hline \multicolumn{2}{|c|}{ CT $(n=45)$ n (\%) } \\
\hline Normal & $14(31)$ \\
\hline Classic/Probable COVID-19 & $26(58)$ \\
\hline İndeterminate for COVID-19 & $4(9)$ \\
\hline Non COVID-19 & $1(2)$ \\
\hline \multicolumn{2}{|c|}{ CT Severity (n=30) n (\%) } \\
\hline Mild & $17(56.6)$ \\
\hline Moderate & $8(26.7)$ \\
\hline Severe & $5(16.7)$ \\
\hline
\end{tabular}




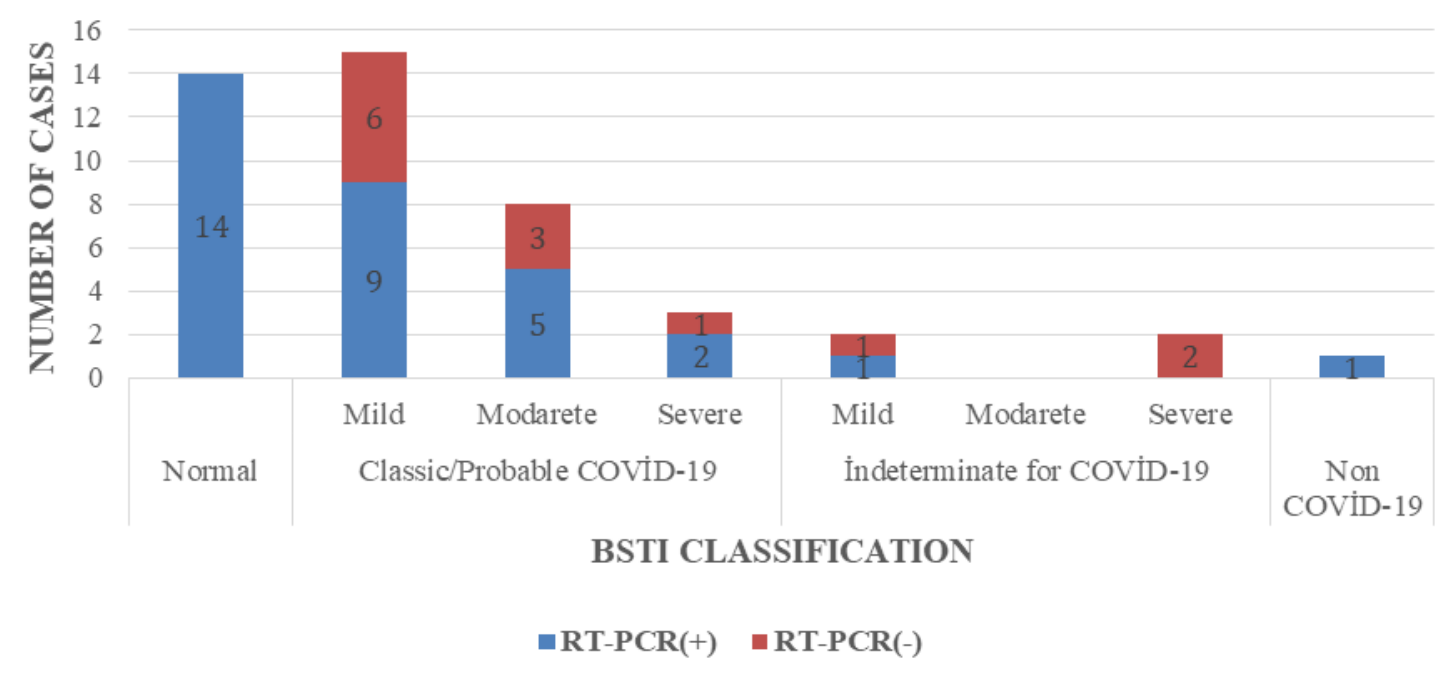

Figure 1.The distribution of cases according to RT-PCR and chest CT scan findings. 


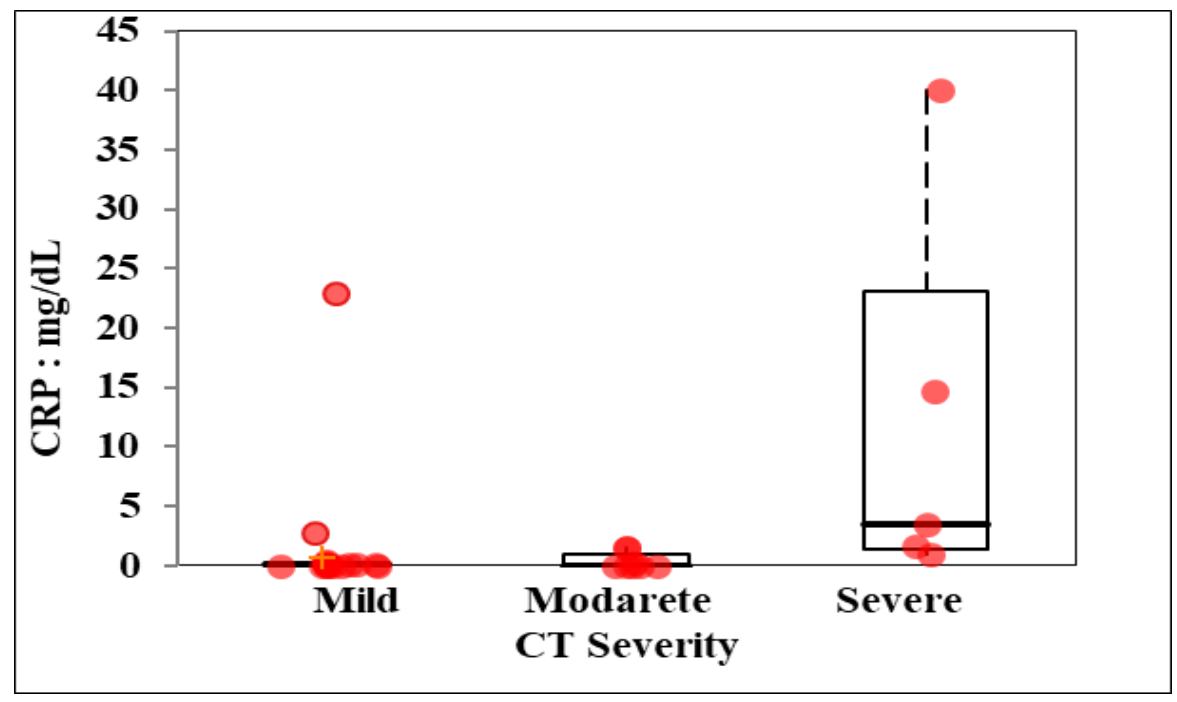

Figure 2.The distribution of cases according to CT scan severity and CRP values. 

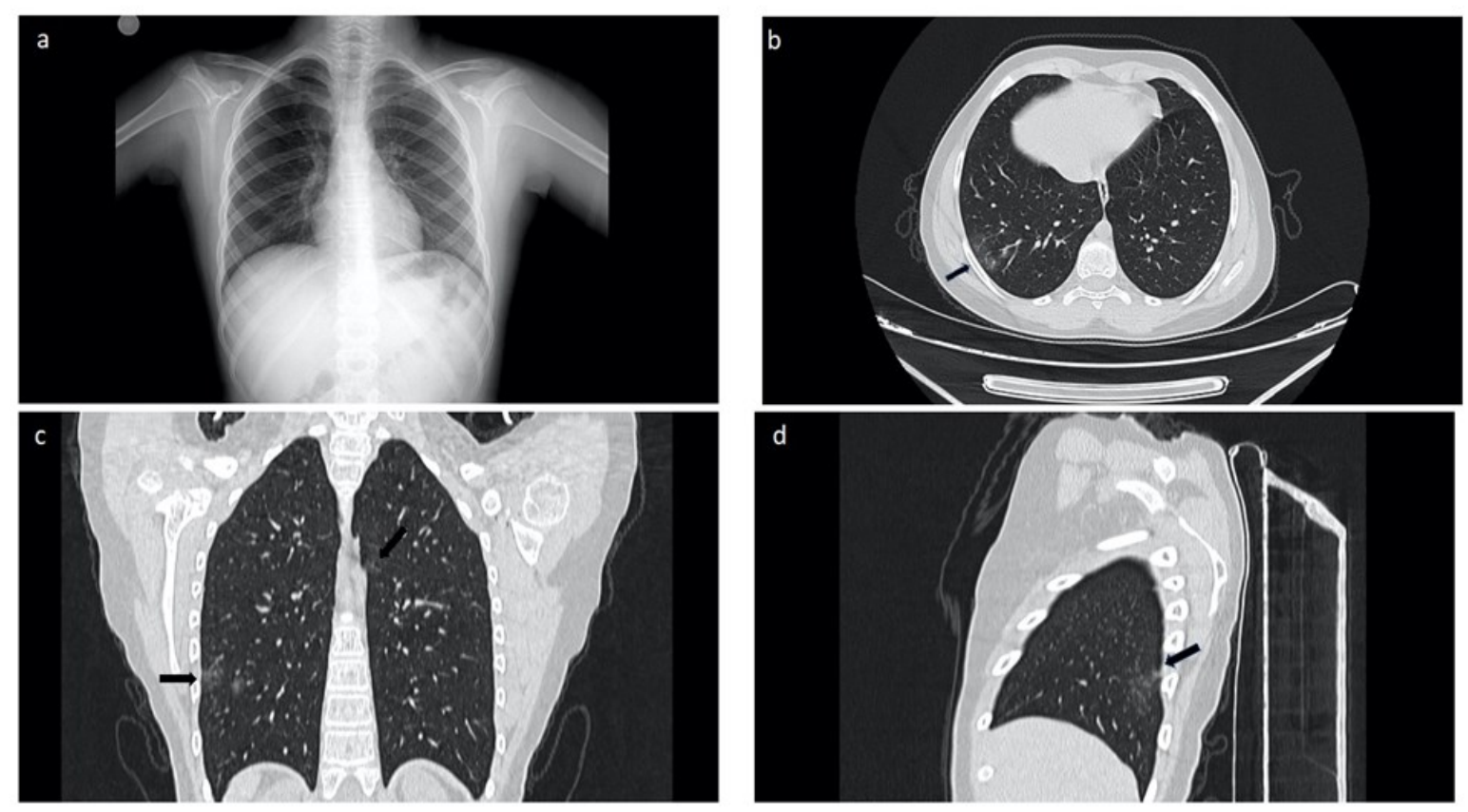

Figure 3. Chest Radiography and Classic / Probable COVID -19 pattern CT scan image.

a) Chest X-Ray shows right perihilar mild opacity.

b) The axial (b) coronal (c) and sagittal (d) chest CT images show bilateral peripheral subpleural patchy ground-glass opacities (GGO) and consolidations (arrows). 